\title{
А.В. Александрова
}

\section{ПРИНЦИПЫ ВЫДЕЛЕНИЯ И ПРОСТРАНСТВЕННО-ВРЕМЕННЫЕ ГРАНИЦЫ КАЙНОЗОЙСКИХ БУРОУГОЛЬНЫХ ФОРМАЦИЙ В ПРЕДЕЛАХ ЮГО-ЗАПАДНОЙ ЧАСТИ ВОСТОЧНО-ЕВРОПЕЙСКОЙ ПЛАТФОРМЫ}

\begin{abstract}
Учитывая многочисленные геологические материалы изучения кайнозойских промышленных угленосных отложений в пределах покровных мегаструктуру юго-западной части Восточно-Европейской платформы, выделены палеоген-неогеновые буроугольные формации с обоснованием особенностей их вещественного состава, строения, распространения, развития, а также взаимоотношений с окружающими неугленосными формационными образованиями.
\end{abstract}

Ключевые слова: бурые угли, Украинский щит, осадочные толщи, формационный анализ, палеотектоника

Вступление. Перемежаемость в осадочном разрезе мезозоя-кайнозоя буроугольных пластов и безугольных, терригенных (песчано-глинистых) образований, наряду с широким латеральным их взаимопроникновением, свидетельствует о парагенетических связях генетически разнородных осадочных отложений морского, прибрежно-морского и континентального происхождения. Такой пространственно-временной породный парагенезис отмечается практически во всех региональных внутриплатформенных отрицательных и положительных структурах западной и юго-западной частей ВосточноЕвропейской платфрормы (ВЕП).

На формационном уровне детальное исследование буроугольных толщ на территории Украины не проводилось. Должного внимания фрормационному анализу кайнозойских отложений осадочного чехла не уделялось, а поэтому до настоящего времени остаются нерешенными вопросы относительно принципов выделения, объема, геотектонического положения, границ угленосных и неугленосных осадочных формационных тел. Исследователи обычно ограничивались выделением конкретных фраций и их типизацией. Реже, по тем или иным признакам, осуществлялось фрормальное (свободное) употребление таксона «формация». Так эоценовая буроугольная формация включает угленосные парагенетические комплексы пород определенного диапазона времени их образования, либо - буроугольная фрормация Украинского щита - по геоструктурной приуроченности углевмещающих отложений и т.д.

Существующая неопределенность точек зрения вокруг выделения фрормаций в рамках исследуемой территории не является бесперспективной, мало значимой, так как разнообразие аспектов комплексного исследования подобного уровня геологических тел (литологический, стратиграфический, тектонический и др.) в совокупности дают представление о месте, времени и условиях образования конкретных формационных объектов в историко-геологической цепочке событий прошлого.

Таким образом, вопрос необходимости и возможности применения классических подходов (методов, инструментов) фрормационного анализа при изучении континентальных и прибрежно-морских угленосных и неугленосных, а также морских (безугольных) отложений мезозоя-кайнозоя остается дискуссионным. Однако имеются все основания для включения фрормационного анализа в единый комплекс геологических исследований рассматриваемых осадочных образований. Накопленный значительный фрактический материал, объединяющий данные о веществанном составе и строении отложений, а также основанные на них палеогеографические, палеоклиматические и

(c) А.В. Александрова, 2013 
палеотектонические реконструкции условий их возникновения, становления и захоронения [2, 3, 5, 7, 13 и др.], позволяетподойти к выделению и всестороннему изучению надпородных естественных ассоциаций (комплексов, сообществ) осадочных пород в фациальноформационном фрормате.

Главные палеотектонические и палеогеографические предпосылки образования угленосных и безугольных формаций. При фациально-формационных расчленениях осадочных толщ, т.е. установлении вертикальных и латеральных границ фраций и формаций, общепринятым является обязательное привлечение результатов региональных палеотектонических и палеогеографических реконструкций на базе данных о вещественном составе, строении и условях залегания пород и их комплексов. В нашем случае следует включать комплекс геологических данных и по прилегающим, смежным территориям с целью восстановления межрегионального хода седиментогенеза окраины древней платформы.

Мезозойско-кайнозойские прибрежно-морские и континентальные угленосные отложения, а также полигенетические безугольные абиогенные и биогенные образования морского происхождения - результат зарождения нового вещества в эволюционном развитии земной коры древней платформы в направлении наращивания осадочного (осадочно-вулканогенного) покрова.

Ранее (в домезозойское время) выразительно обособленные, контрастно развивающиеся ключевые структуры Большого Донбасса (Припятская и ДнепровскоДонецкая впадины, Донецкое складчатое сооружение), Украинского щита (Ущ), Приазовского кристаллического массива (ПКМ), Воронежского кристаллического массива (ВКМ), Причерноморской (ПВ) и Львовско-Волынской (ЛВВ) впадин, а также сопряженные, переходные региональные структуры (Приднепровская, Сейм-Северско-Донецкая, Причерноморская, Подольская плиты) по строению, составу и условиям образования вмещающих их осадочных отложений приобретают (начиная с мезозоя) облик единой «окраинной» мегаструктуры ВЕП, в пределах которой отмечается доминирующий и выдержанный мелкообломочный (песчано-глинистый) состав отложений, субгоризонтальное залегание пластов, постепенные вертикальные и латеральные сочленения (переходы) пород, частая перемежаемость (тонкое переслаивание) относительно маломощных составляющих пачки пород, широкий (триас-неоген) пространственно-временной диапазон распространения углистого вещества в рассеянном состоянии вплоть до промышленных скоплений в виде многопластовых залежей бурого угля.

Морские трансгрессии-регрессии, вызванные колебаниями земной коры и эвстатическими изменениями уровня Мирового океана, определили пространственновременные масштабы процессов седиментогенеза. Их количество (частота), продолжительность, амплитуда $и$ направленность отразились на конечном облике погребенных фрациально-формационных тел. Процесс формирования и захоронения последних чаще всего ограничивался континентальными перерывами в осадконакоплении. Положение плавающей береговой линии, отделяющей области морского и континентального осадкообразования контролировалось конфигурацией областей устойчивой денудации, т.е. длительное время пульсирующими региональными поднятиями выступов докембрийского фрундамента (УЩ, ВКМ, ПКМ), а также полосой складчатых сооружений Крымско-Карпатской системы на фроне устойчивого (до позднего палеогена) колебательного погружения западных, юго-западных и южных частей ВЕП.

Анализ площадного (территориального) распространения, конкретных особенностей петрографрического состава и строения болотных фрациальных комплексов пород, формировавшихся в различных региональных структурно-геоморфологических обстановках, а также миграции углевмещающих фраций в разрезе свидетельствует об относительно одинаковых фризико-географических условиях их образования в спокойной эпейрогенической тектонической обстановке как в мезозое, так и в кайнозое, с отдельными всплесками локальной вулкано-плутонической активизации, особенно в начале кайнозоя. Морфология и объемы (размеры) прибрежно-континентальных и континентальных 
фациальных тел и их закономерных сочетаний крайне изменчивы и прямо зависели от строения обычно унаследованных (обновленных) отрицательных форм ложа осадконакопления (река, озеро, лагуна, залив).

На киммерийском (триас-мел) этапе развития юго-западной части ВЕП настала эпоха наращивания и расширения площадей осадочного покрова за счет вовлечения в процесс прогибания пограничных территорий длительное время возвышающихся выступов докембрийского фундамента (УЩ, ВКМ, ПКМ). Особенно значительное субмеридиональное латеральное расширение седиментогенеза прослеживалось в стороны от ПрипятскоДнепровско-Донецкой геоструктурной зоны (субгеосинклинали) - палеозойской региональной линейной области морского и континентального осадконакопления. В ее пределах - доминирующие и значительные по размерам, слабо наклоненные и асимметричные субсинклинально-моноклинальные структуры - были аренами преобладающего морского и лагунного терригенно-карбонатного седиментогенеза, а подчиненные разнообразные положительные морфоструктуры - либо районами размыва, либо континентальной, реже лагунной аккумуляции преимущественно терригенных осадков. Такое постепенное присоединение частей соседних (склоновых) рельефно неоднородных докембрийских выступов фундамента в общее прогибание привело к появлению в прибрежно-континентальной и собственно континентальных зонах незначительных (локальных) понижений, в которых фрормировались палеоторфяники, фрагментарно представленные в виде малопродуктивных углевмещающих толщ (северо-западные и юговосточные районы УЩ). Кроме того, следует отметить, что в конце рассматриваемого этапа произошли перестройки на южном и юго-восточном фрлангах Большого Донбасса в связи со складчатыми процессами, которые охватили Донецкую мегаструктуру и ее обрамление на границе мела - палеогена.

В целом, не исключая возможности фрормирования торфяников в благоприятных структурно-геоморфологических условиях в присклоновых и собственно склоновых зонах, окружающих УЩ и другие мегавыступы во время периодического обмеления и полного отступления морей-лагун, следует отсутствие условий для фоомирования и захоронения значительных по объему торфяников на протяжении киммерийского этапа развития мегаструктур юго-западной части древней платформы.

Альпийский (палеоген-неогеновый) этап в эволюции юго-западной окраины ВЕП ознаменовался значительными изменениями распространения областей аккумуляции и денудации отложений. Причиной тому стали активные орогенные процессы в молодых геосинклиналях юга платформы, а также складкообразование в пределах Донецкой субгеосинклинали. Донецкая, длительное время аккумулирующая структура, становится ареной глубокого размыва ранее сформированных мощных верхнепалеозойских $и$ мезозойских толщ, а непосредственное (Западный Донбасс) и относительно отдаленное (Припятско-Донецкая структура и плиты) окружение продолжает или становится (УЩ, ВКМ, ПКМ) областями накопления осадков в устойчивого (фонового) погружения ВЕП. Такая геодинамическая обстановка способствовала постепенному наращиванию и значительному расширению площадей морской и континентальной аккумуляции и соответственно относительному сужению и территориальному перераспределению областей активной денудации в широком временном диапазоне (палеоген-неоген), а также фрациальному разнообразию условий торфообразования в промышленных масштабах (Днепровский буроугольный бассейн - ДББ, Днепровско-Донецкий буроугольный район - ДДБР). Отмеченный исследователями [5, 19] миграционный переход продуктивного углеобразования от карбоновой структуры Большого Донбасса через палеоцен-эоценовые осадочные покровные структуры УЩ к олигоцен-миоценовым локальным структурным единицам Днепровско-Донецкой впадины (ДДВ) является ярким отображением пространственно-временного контроля хода седиментогенеза со стороны сочетающихся глобальных (колебательных), региональных (пликативных) и локальных (диапировых) процессов. 
В пределах юго-западной части ВЕП отмечался ряд фаз альпийской активизации тектонических движений, которые приводили к периодическим изменениям облика областей денудации-аккумуляции, т.е. к перестройке рельефра территории. В результате активизации тектонических движений возникали новые или обновлялись (наследовались) системы линейных, дуговых и кольцевых разнопорядковых дизъюнктивных нарушений (разломы), а также пликативные (прерывчатая мелкоамплитудная складчатость) и инъективные проявления (соляные и глиняные диапиры). С каждой фразой активизации связано возобновление интенсивного осадконакопления, а с периодами относительного тектонического покоя - резкое снижение масштабности процессов размыва, переноса и отложения абиогенного и биогенного материала. Это приводило к постепенной пенепленизации территории и не способствовало захоронению органического вещества, которое подвергалось разложению и рассеиванию на поверхности ранее сфрормированных осадков.

Подходы к выделению, определению названия и положению угленосных формаций среди других осадочных ассоциаций. В юрско-неогеновом диапазоне времени формирования углевмещающих осадочных толщ юго-западной окраины ВЕП исследователями выделен ряд пиков (этапов) торфообразования, зафиксированных в среднеюрских (байосс, бат), нижнемеловых отложениях, а также - с максимальным продуктивным развитием - в толщах средне-позднепалеогенового (эоцен, олигоцен) и реже ранненеогенового (миоцен) возраста [5, 11, 13, 19 и др.]. Последнее обстоятельство, т.е. возрастное распространение угленосных образований в промышленных масштабах, а также геоструктурная приуроченность (позиция) вмещающих их отложений, положены автором в основу выделения и определения названий угленосных фрормаций: нижнесреднепалеогеновая (палеоцен-среднеэоценовая) буроугольная фрормация Украинского щита и такого же ранга - верхнепалеоген-нижненеогеновая (олигоцен-миоценовая) буроугольная фрормация Днепровско-Донецкой впадины (синеклизы).

Вслед за Г.Ф. Крашенинниковым [15], Г.А. Ивановым [10] и другими исследователями автор рассматривает «угленосную формацию» в качестве обособленного полифациального тела, обязательно содержащего болотные фации в окружении близких, парагенетически связанных (не всегда углевмещающих) литогенетических комплексов, а под «угленосными толщами» (или отложениями) - осадочные образования, обычно вмещающие промышленные угольные пласты или залежи. В основу же выделения конкретных угленосных фрормаций положены следующие известные определяющие признаки (особенности) изучаемых ассоциаций пород:

1. Палеоген-неогеновый возраст.

2. Однотипность набора литотипов пород (уголь, песок, глина, реже алеврит, мергель).

3. Уголь - фрормационнообразующая (маркирующая) порода.

4. Бурый уголь - качество (степень метаморфизма) угля.

5. Формирование в эпоху альпийской тектонической и тектоно-магматической активизации древней платформы.

6. Генетические и парагенетические особенности формирования отложений, т.е. фризико-географические условия осадконакопления (лимнические в обстановке влажного и теплого ( гумидного) климата).

Нижне-среднепалеогеновая (палеоцен-среднеэоценовая) буроугольная формация Украинского щита. Обычно исследователи сужают возрастные границы образования углевмещающей толщи ДББ, т.е. ограничиваются среднеэоценовым диапазоном времени континентального (реже прибрежно-морского) фрормирования осадков. Это приводит к выпадению нижних и верхних породных парагенезисов начального и завершающего (переходных) этапов образования угленосной формации. Для такого суждения нет достаточных оснований, так как бесспорным является развитие значительной предпалеогеновой - позднемеловой (сеноман-дат) - морской трансгрессии в пределах ДДВ и ПВ. Последняя сопровождалась активными локальными прибрежно- 
континентальными вулканическими проявлениями на северо-восточном склоне УЩ до начала формирования отложений формации - с одной стороны, и завершением образования рассматриваемых континентальных и прибрежно-лагунных формационных комплексов к началу последней значительной (охватывающей значительную территорию щита) позднепалеогеновой (киевской) трансгрессии моря - с другой, что значительно расширяет возрастной диапазон формации.

Площадное развитие угленосной фрормации ограничено контурами УЩ, т.е. склоновыми и приосевыми (водораздельными) его зонами. Для определения нижней стратиграфической границы полного разреза формации следует остановиться на вещественном составе и строении подстилающих ее отложений на рубеже позднего мелараннего палеогена (палеоцена). Так уже отмечалось, к этому времени завершилась обширная (охватившая большую часть УЩ) позднемеловая ингрессия моря со стороны соседних устойчиво прогибающихся мегадепрессий и активизировалась (в начале палеогена) тектоническая и тектоно-магматическая деятельность в периферийных зонах щита [3, 5]. Указанные события обусловили возникновение палеоценовых прибрежноморских (лагунных и дельтовых) ландшафтов, а также способствовали заложению линейноветвистых и замкнутых отрицательных форм рельефа эрозионно-денудационного $и$ тектонического происхождения, в пределах которых осуществлялось начальное накопление преимущественно прибрежно-морских и континентальных терригенных толщ формации. На конечный облик последних существенным образом влияла продолжительность отдельных фраз и циклов трансгрессий-регрессий морей в окружающих региональных депрессиях, а также их количество, амплитуда и направленность.

Важно отметить резкую смену в разрезе и по латерали (по направлению к УЩ) относительно глубоководной (удаленно-шельфовой) мел-мергелистой ассоциации осадков (карбонатная формация) позднемелового возраста первоначально мелководными (шельфовыми) глинисто-мергелистыми и песчано-глинистыми комплексами пород (терригенно-карбонатная фрормация), а затем прибрежно-континентальными и континентальными терригенными осадочными и осадочно-вулканогенными отложениями палеоцена. В пределах склонов и на некотором удалении в глубь щита верхнемеловые формации не всегда подстилают нижнепалеогеновую часть рассматриваемой фоомации. Неоднородный поясовой размыв подстилающих толщ, возрастающий по направлению к осевой наиболее приподнятой зоне щита, привел к угловым и стратиграфическим несогласиям между породными комплексами.

По-видимому, наиболее полные сохранившиеся разрезы рассматриваемой формации следует искать на юго-восточных и северо-восточных первоначально втянутых в прогибание окраинах УЩ в непосредственной близости от областей начальной аккумуляции осадков, вызванной нарастающими трансгрессиями палеоцен-эоценовых морей в северозападном направлении согласно простиранию структур Большого Донбасса.

Постепенное проникновение моря в сторону Припятской впадины привело к формированию в пределах Припятско-Днепровско-Донецкой мегадепрессии трансгрессивного ряда осадочного цикла, объединяющего сумскую, каневскую, бучакскую и киевскую свиты, а в полосе сочленения с УЩ и на самом щите - развитие прибрежноморских и континентальных аналогов перечисленных свит (за исключением киевской свиты) в обстановке динамического равновесия или колебания щита при фроновом, устойчивом поднятии последнего. Такой, переходной, крайне изменчивый пространственно-временной режим седиментогенеза привел к разнообразным соотношениям породных и фациальных тел.

В основании разреза фрормации на склоне щита залегает (на различных срезах кристаллических пород докембрия, палеозой-мезозойской коры выветривания, триасмеловых отложений) мелководная (лагунная) песчано-глинистая толща сумской свиты, мощность которой не превышает 50 м, а в пределах кольцевых депрессий Среднего Приднепровья - прибрежно-морской (лузановская свита - до 20 м) и континентальный (райгородская толща - до 60 м) осадочно-вулканогенный комплекс пород (вулканические 
брекчии, туфопесчаники, пепловые туфы, глины, кварц-глауконитовые пески) [3, 5]. Литофациальные особенности удаленных от морского побережья внутриконтинентальных обстановок фрормирования осадков сумской и каневской свит охарактеризуем ниже из-за неоднозначной трактовки (разночтения) исследователями объема и стратиграфического положения так называемой «бучакской толщи».

На фроне общего прогибания юго-западной части ВЕП в раннеэоценовое время наблюдается возрастающее развитие мелководных морских обстановок осадконакопления, постепенно захватывающих территорию ДББ. Дальнейшее наращивание различных разрезов фрормации осуществляется за счет каневских прибрежно-морских и континентальных отложений, относительно хорошо изученных в районе Каневских дислокаций, где они сложены глауконит-кварцевыми песками с прослоями алевритов, кремнистых песчаников, углистых и безуглистых глин морского и прибрежно-морского генезиса. Континентальная же часть свиты наиболее полно представлена в пределах Кировоградского блока щита, где она сложена глинистыми и углистыми песками (мощностью до 10-15 м), нередко вмещающими маломощные (до 2 м) прослои и линзы песчаников и бурых углей $[5,18]$.

Принято полагать, что континентальные отложения каневской свиты постепенно сменяются вверх по разрезу формации продуктивной ее частью, которая представлена континентальными песками бучакской свиты, вмещающими прослои и линзы глин, песчаников, бурых углей. Мощность свиты в среднем составляет 25-35 м, редко достигая 70 м и более. В разрезе континентальной толщи бучакской свиты исследователи выделяют нижнюю (подугленосную) и верхнюю (угленосную) части. Общая их мощность - до 40 м [5, $14,18]$.

Прежде чем продолжить описание петрографического состава, строения и условий образования верхней части разреза формации, следует остановиться на проблеме неоднозначного толкования времени фрормирования прибрежно-морской и континентальной «бучакской углевмещающей толщи (свиты)» УЩ, т.е. ее стратиграфрического положения (места) в палеогеновой системе и соотношения с морскими довольно хорошо стратифицированными отложениями ДДВ.

Одни исследователи - а их большинство - помещают толщу в сводной стратиграфической колонке между каневской и киевской свитами и рассматривают ее в качестве континентального аналога морской бучакской свиты (средний эоцен) [5, 18, 19 и др.]. Другие же ставят вопрос о расширении возрастного диапазона образования континентального «бучака» за счет значительного "удревнения» его возраста (палеоценсредний эоцен) [5, 14].

Результаты комплексного изучения и обобщения фрактического материала не противоречат выводу о более длитетельном, палеоцен-среднеэоценовом возрастном интервале образования континентальных угленосных отложений УЩ. Действительно, в региональных депрессиях (ДДВ, ПВ) трансгрессивная направленность палеоцен-эоценового морского седиментогенеза не ограничивалась формированием только удаленношельфовых и шельфовых фаций и их ассоциаций (формаций), объединяющих, как уже отмечалось, отложения сумской, каневской, бучакской и киевской свит. По направлению к щиту логично ожидать присутствие прибрежно- морских (лагунных) и континентальных (озерных, речных) аналогов перечисленных свит. Естественно, что наиболее благоприятными для аккумуляции осадков были наиболее погруженные области щита (склоновые зоны, обширные северо-восточные наклоненные территории, сеть разнопорядковых замкнутых депрессий и речных долин), в которые или вдоль которых осуществлялось проникновение лагунных вод.

Если проанализировать характер изменения мощностей морских отложений палеоцена-среднего эоцена от ДДВ к УЩ, то выясняется, что при средней мощности отдельных свит (40-50 м) происходит постепенное равномерно распределенное посвитное уменьшение их мощности в прибрежно-лагунной (15-25 м) и озерно-речной (5-10 м) ландшафтных зонах, вплоть до полного выклинивания на щите. По данным 
исследователей, мощность бучакской свиты в глубоководной части ДДВ не превышает 40 м, локальных просадках - до 80-100 м, а на бортах - не более 5-20 м [7, 14, 16]. В континентальной же зоне мощность свиты колеблется в пределах 25-35 м, редко достигая 70 м и более [14, 16]. Следовательно, в 25-35-метровых разрезах « бучакской толщи» УЩ должны присутствовать в различных соотношениях равнозначные горизонты прибрежно-лагунных и континентальных осадочных, реже вулканогенно-осадочных угленосных отложений сумской, каневской, бучакской и киевской (?) свит палеоценасреднего эоцена.

После приведенного выше важного отступления, вернемся к характеристике состава, строения и условий образования «бучакской толщи» $[5,18]$. Верхнюю (угленосную) ее часть на три горизонта. Нижний представлен разнозернистыми песками, вмещающими прослои углистых глин и вторичных каолинов (пойменная и старичная фрации); средний содержит пласты бурого угля (озерно-болотная фрация долинных отложений); верхний сложен песчано-алеврито-глинистыми углистыми отложениями с прослоями вторичного каолина и песчаника (болотная фрация).

Верхним (надугольным) песчано-глинистым горизонтом «бучакской толщи» завершается разрез рассматриваемой формации, который перекрывается преимущественно морскими отложениями киевской свиты (средний эоцен) (карбонатнотерригенная фрормация). В основании последней залегают фросфоритоносные известковоглинистые пески (до 5 м), переходящие вверх по разрезу в кварц-глауконитовые пески и мергеля мощностью до $15 \mathrm{~m}$. Не исключается возможность нахождения маломощных континентальных углистых песков на некотором удалении от возвышенного водороздела УЩ.

Своеобразное поведение, т.е. непостоянство поперечного площадного распространения, различная длительность и амплитуда палеогеновых трансгрессийрегрессий моря в пределах преимущественно колебательно прогибающихся структурно очерченных территорий ДДВ и ПВ, отразилось на особенностях вещественного состава, строения и границ развития фрациально-формационных тел в переходной (прибрежноморской) и континентальной ландшафтных зонах-поясах.

Таким образом, в объем рассматриваемой буроугольной фрормации автором включены осадочные и вулканогенно-осадочные отложения сумской, каневской, бучакской свит, формирование которых осуществлялось в прибрежно-лагунных и континентальных (аллювиально-озерных) ландшафтных обстановках.

Как уже отмечалось, киевской трансгрессией моря была охвачена практически вся юго-западная территория ВЕП, включая и УЩ. Этой ингрессией завершился трансгрессивный ряд седиментационного цикла (мел-средний палеоген), после которого наступил цикл осадконакопления регрессивного ряда в соседних мегадепрессиях. Эта смена направленности седиментогенеза непосредственно отразилась и на накоплении прибрежно-морских и континентальных осадков позднего палеогена-раннего неогена (обуховская, межигорская, берекская, новопетровская свиты) на территории щита.

Верхнепалеоген-нижненеогеновая (олигоцен-миоценовая) буроугольная формация Днепровско-Донецкой впадины. В различных публикациях автора и других исследователей достаточно подробно охарактеризованы геологические особенности строения и условия образования верхнепалеогеновых и нижненеогеновых угленосных отложений ДДВ [2, 7, 9, 13 и др.]. Поэтому, кратко рассмотрим вещественный состав, стратиграфическое положение, генезис, пространственно-временные соотношения подстилающих, слагающих и перекрывающих породных парагенезисов формации.

Миграция торфообразовательных процессов в пределы длительное время колебательно погружающейся Припятско-Днепровско-Донецкой геоструктурной зоны было предопределено региональной активизацией соляного тектогенеза. В результате локальной пульсационной диапировой деятельности, охватившей значительные площади центральной (приосевой) и прибортовых зон впадины, в присводовых областях соляных куполов возникли замкнутые и открытые (овальные и дугообразные) отрицательные фрормы 
рельефра (депрессии над- и прикупольного типов). Временной диапазон активных солянотектонических проявлений был различный и зависел от их количества, масштаба и сочетания с региональными колебательными движениями.

После максимальной киевской ингрессии моря, охватившей юго-западную часть ВЕП, наступила эпоха частых и кратковременных мелкоамплитудных трансгрессивнорегрессивных циклов колебания мелководных морей и лагун на фоне постепенного регионального их обмеления (регрессии, отступления моря). Среди морских, прибрежноморских и континентальных осадочных комплексов выделяются фации мелководного моря, мелководных опресненных открытых, полузамкнутых и замкнутых лагунных водоемов, русел и пойм рек с замедленным течением, застойных озерных водоемов.

В пределах Днепровско-Донецкой угленосной площади, вмещающей более 40 месторождений и углепроявлений бурого угля, В той или иной степени угленосными являются отложения харьковской серии, представленной обуховской (верхний эоцен) и межигорской (нижний и средний олигоцен) свитами, а также полтавской серии, включающей отложения берекской (верхний олигоцен) и новопетровской (нижний миоцен) свит. Наиболее полные продуктивные разрезы формации отмечены в центральных и юговосточных районах приосевой зоны впадины, в пределах надкупольных просадок-воронок. Вмещающие угленосные отложения прикупольные (меж- и околокупольные) депрессии распространены главным образом в пределах северо-восточной и юго-западной прибортовых зон впадины. Площадь развития разобщенных углевмещающих депрессий колеблется в пределах 10-1200 кв.км. В центральных и близповерхостных районах описываемых наложенных отрицательных структур отмечаются сравнительно простые взаимоотношения угленосных и безугольных горизонтов с некоторым усложнением характеристик залегания отложений на периферии структур и с глубиной.

Для устойчиво морской аккумулятивной структуры ДДВ характерно послойное накопление палеоцен-миоценовых преимущественно морских песчано-глинистых отложений. Отмечается повсеместное плавное $\left(1-2^{\circ}\right)$ погружение толщ от бортов впадины в сторону ее центральной (приосевой) зоны. Субгоризонтальное залегание пород нарушается в областях проявления соляных диапиров, где падение слоев достигает 5-7. По направлению к осевой части впадины закономерно увеличивается мощность свит от 10 до 80 м с локальными максимумами (до 370 м) в над- и прикупольных депрессиях. Существование в ДДВ областей, отличающихся петрографическим составом, строением и мощностью слагающих их осадочных образований, обусловило выделение четырех типов разреза кайнозоя. Первый тип охватывает бортовые зоны впадины, склоны и своды локальных поднятий; второй - осевую (центральную) зону впадины за пределами развития солянокупольных структур; третий - надкупольные депрессии; четвертый - прикупольные депрессии.

В настоящей работе не было предусмотрено всестороннее изучение палеогеновых неугленосных полифациальных осадочных комплексов, которые подстилают, перекрывают и латерально замещают верхнепалеогеновую угленосную фрормацию с целью фрациальноформационного расчленения и выяснения их соотношений. Поэтому основное внимание уделено изучению углевмещающих локальных депрессий солянокупольных областей.

Полнота разрезов формации в регионе весьма различна от депрессии к депрессии. В пределах большинства угленосных структур не были вскрыты нижние горизонты формации (отложения обуховской и нижнемежигорской частей свит). На большей части центральной зоны ДДВ (вне солянокупольных областей) отложения обуховской свиты представлены бескарбонатными глинистыми алевритами и алевролитами (35-40 м), реже опоковидными песчаниками и трепеловидными глинами, а на бортах - бекарбонатными песчанистыми глауконитовыми алевритами и глинами (0,5-10 м) [5, 19].

Мощный разрез отложений межигорской свиты вскрыт в центральной части Новодмитровской надкупольной депрессии (юго-восточная часть региона). Нижняя часть свиты представлена мощной (19 м) линзой бурого угля залегающей на песках обуховской свиты (82 м), а перекрывается пачкой песчаных глин, переходящих в глауконитовые пески 
(35 м). Верхняя часть сложена темноц-ветными и сероцветными песками, вмещающими прослои углистых глин, как правило, приуроченных к маломощным пластам бурого угля. Мощность межигорской свиты в этой структуре составляет 143 м [14, 15].

В большинстве надкупольных депрессий отложения свиты имеют глинисто-песчаный состав. Мелкозернистые пески и песчаники залегают в нижних и верхних частях разрезов, а в средних - глинистые и глинисто-алевритовые, которые к краям депрессии постепенно замещаются мелкопесчаными образованиями. В отдельных депрессиях северо-западных окраин Донбасса в средних и нижних частях глинисто-песчаной толщи отмечены пласты бурого угля. В северо-западной группе депрессий мощность свиты в центральных частях составляет 45-50 м, а в краевых зонах - 5-10 м. В надкупольных депрессиях центральной приосевой области впадины мощность свиты колеблется от 60 до 150 м с резким сокращением мощности от 10 до 50 м - к краям структур.

Разрезы свиты прикупольных депрессий прибортовых зон впадины представлены мелкозернистыми глауконит-кварцевыми песками с прослоями песчаников и нередко - в средней части - пластами глауконитовой глины. В пределах северо-восточной прибортовой зоны мощность отложений свиты в депрессиях от 100 до 250 м, а на юго-восточных склонах - 45-160 м. В отличие от надкупольных структур, они характеризуются значительно выдержанной по площади мощностью субгоризонтально залегающих пластов пород.

Выше по разрезу на юго-востоке центральной части региона (за пределами солянокупольных структур) зафиксированы полные (до 35 м) безугольные разрезы берекской свиты с двухчленным строением: нижняя часть представлена тонкосланцеватыми глинами, сменяющимися по направлению к поднятиям толщей переслаивающихся глин и мелкозернистых кварцевых песков либо ожелезненными разнозернистыми песками с глыбами железистых песчаников; верхняя - светлыми горизонтально- и косослоистыми мелкозернистыми песками. По направлению к бортам впадины наблюдается постепенное замещение глинистых и глинисто-алевритовых отложений песчаными.

Над- и прикупольным депрессиям солянокупольных областей свойствен в основном песчаный и углисто-песчаный состав берекских отложений. Исключение составляет Новодмитровская отрицательная структура, которая вмещает толщу гипсово-карбонатных пород. Во всех структурах в составе свиты встречаются либо пласты бурого угля, а также прослои песков и глин, обогащенные пелитоморфной органикой и растительным детритом, либо только углистые глины и пески.

Для отложений берекской свиты характерны подобные межигорским образованиям изменения мощности: она возрастает от бортов впадины к ее центральной части, резко увеличиваясь в пониженных участках и уменьшаясь на поднятиях. В центральной части впадины средняя мощность свиты не превышает 35 м, в направлении бортов сокращается до 20 м, а на бортах и склонах отдельных поднятий составляет 5-10 м. В депрессиях надкупольного типа мощность толщи наращивается в юго-восточном направлении от 20 и до 100 м - на крайнем юго-востоке. Такие же изменения прослеживаются при анализе мощностей в прикупольных структурах (25-180 м).

Глинисто-песчаные отложения новопетровской свиты, перекрывающие берекские образования, наиболее полно представлены на северо-восточном и юго-западном бортах впадины, а также в глубоких надкупольных, реже прикупольных прогибах. Контакт между свитами преимущественно четкий, хорошо выдержан. В центральной части региона к нему приурочены прослои и линзы грубозернистых, гравелистых песков и песчаников, а на бортах впадины - пласты углистых глин, бурого угля, разнозернистых песков. В надкупольных, реже в прикупольных структурах граница между отложениями свит фиксируется по подошве пластов бурых углей и диатомовых глин.

В составе отложений новопетровской свиты выделено три пачки. Нижняя пачка состоит из разнозернистых косослоистых песков, вмещающих линзы и прослои гравия, а также горизонты кремнисто-кварцевых песчаников. Иногда наблюдаются тонкие прослои углей, залегающие в мелкозернистых углистых песках и углистых глинах. Средняя пачка 
представлена светло-серыми горизонтально- и косослоистыми мелкозернистыми песками с прослоями разнозернистых глинисто-кремнистых и железистых песчаников, а также пластами светло-серых и белых алевритистых глин. Верхняя пачка вмещает светло-серые, реже малиновые и охристо-желтые каолинистые мелкозернистые пески и уплотненные разнозернистые песчаники.

На бортах впадины мощность разрезов свиты изменяется от 5 до 15 м. Причем в наиболее погруженных участках бортов достигает 35-45 м. В надкупольных депрессиях мощность отложений составляет 20-80 м (в Новодмитровской структуре - 130 м), а в прикупольных - 5-30 м (из-за значительного размыва верхних частей свиты).

В течение обуховского и межигорского веков территория ДДВ была покрыта водами мелкого эпиконтинентального моря. Начиная с позднего эоцена прогрессирующее поднятие УЩ привело к обмелению и сокращению морского бассейна. В периоды максимального обмеления раннемежигорского моря вдольбереговые зоны, а также удаленные от берега цепочки пологих и небольших по размеру островов, периодически выступали над уровнем моря. Обводненность, влажный и теплый климат способствовали произрастанию в этих районах пышной субтропической растительности, ставшей исходным материалом для образования торфяных залежей в приостровных участках мелководья и прибрежных зонах. Однако из-за контрастной динамики морской среды не создавались благоприятные условия для существенного накопления и захоронения растительного материала: на островных участках первичной аккумуляции растительности наблюдаются уцелевшие от перемыва и переотложения реликтовые мозаичные скопления обуглившейся органики, а вдоль побережий - как рассеянные растительные остатки, так и небольшие по размерам и мощности торфяные залежи.

В раннемежигорское время на фоне мелкоамплитудных колебательных движений выделялись локальные непрерывно-прерывистые воздымающиеся солянокупольные области прибортовых зон впадины, в присводовых частях которых либо вовсе отсутствуют отложения рассматриваемого отрезка времени, либо представлены маломощной толщей песков с редкими включениями растительных остатков. В центральных частях надкупольных депрессий (особенно с высоким гипсометрическим уровнем залегания) формировались изолированные от динамически активной морской среды водоемы, в которых во время максимальных регрессий моря происходило понижение уровня поверхностных и грунтовых вод и как следствие - заболачивание территории и образование торфяников.

После среднемежигорской трансгрессии моря, вызвавшей частичное расширение площади морского бассейна и осаждение глауконит-кварцевых песков в соответствии с устоявшимся рельефом морского ложа, наступила очередная позднемежигорская регрессия мелководного моря. Накопление осадков в этот отрезок времени было практически идентичным осадконакоплению в начале межигорского века. Наличие косой слоистости, знаков волновой ряби, а также разнозернистый состав отложений, вмещающих рассеянные включения органических остатков, дают основание предположить, что глубина мелководных участков (прибрежно-морские зоны и присводовые области солянокупольных структур) составляла первые метры. Глубина межигорских морей в других частях впадины, где происходило формирование монотонных по составу (песчаных) и простых по строению осадков, не превышала 15-25 м. Максимальные же глубины бассейнов (40-60 м) отмечены в районах аккумуляции алеврито-пелитовых пород [7].

В начале берекского века на месте мелеющего позднемежигорского моря появляется лагуна, связанная с отступающим на северо-запад и юго-восток морем. Периодические поднятия региона сопровождались частыми обмелениями обширной лагуны, на месте которой возникала широкая сеть разнообразных по размеру остаточных озерных и озерно-болотных водоемов, а также водотоков с различным режимом течения. Территория ДДВ представляла собой аккумулятивную равнину, периодически затапливаемую лагуной, а примыкающие с северо-востока и юго-запада зоны прибрежной суши можно рассматривать в качестве низменной денудационной равнины. На пестроту и особенности осадочного 
процесса в существовавших озерных, руслово-пойменных и болотных обстановках доминирующее влияние оказывали параметры поодиночных и сгруппированных локальных положительных структур, т.е. их размеры, морфология, а также динамика (частота, скорость, амплитуда) разнонаправленных перемещений областей размыва и накопления осадков.

В позднеберекское время произошла кратковременная регрессия моря, которая была последней, завершающей в палеоцен-олигоценовом трансгрессивно-регрессивном ряду развития юго-западной части ВЕП. Глубина эпиконтинентального моря составляла 1520 м, а в наиболее погруженных депрессиях доходила до 35 м. Море не выходило за пределы впадины. Солянокупольные поднятия возвышались над уровнем моря, образуя отдельные острова, либо группы островов, в центральных частях которых продолжали существовать озера, периодически трансформирующиеся в болота. По периферии этих озер (болот) произрастала ольха, ива, болотный кипарис, папоротники, плауны $[7,15]$.

С новопетровского времени на исследуемой территории отмечается устойчивый континентальный режим осадконакопления. Регион представлял собой низменную аккумулятивно-денудационную равнину с переменной и мигрирующей сетью речных, озерных и болотных обстановок. По-прежнему поднятия являются основными источниками терригенного и органогенного материала, поступающего в локальные впадины. Однако, все чаще наблюдаются признаки некомпенсированного прогибания, обусловившего обмеление и зарастание озер надкупольных просадок с последующим образованием на их месте обводненных и торфяных болот. Характерные для ранних этапов новопетровского времени руслово-пойменные среды со временем уступают место озерным и озерно-болотным обстановкам. Угасанию торфообразовательных процессов способствовала постепенная аридизация климата, приведшая к видовой смене лесной растительности лесостепной и степной $[7,15]$. Отложениями полтавской серии завершется разрез угленосной формации, который перекрывается континентальными толщами верхнего миоцена, плиоцена и четвертичной системы.

Заключение. 1. В конце неогея, в связи с периодически нарастающим вовлечением в погружение значительных территорий УЩ, ПКМ и ВКМ, сформировалась относительно широкая кайнозойская аккумулятивная впадина с плавающими геоструктурными границами. Такая эволюционирующая мегаструктура контролировала постепенное пространственновременное перемещение ландшафтных обстановок осадко- и торфообразования.

2. Региональные угленосные структуры (УЩ, ДДВ) вмещают угленосные отложения широкого диапазона времени образования (юра-неоген). Максимальные этапы торфонакопления вначале проявились в устойчиво воздымающихся областях выступов докембрийского фрундамента на протяжении раннего-среднего палеогена (ДББ), а затем завершились в пределах наложенных длительно прогибающихся покровных мегаструктурах юго-запада ВЕП в позднепалеоген-ранненеогеновом диапазоне времени (ДДБР).

3. В пределах исследуемой части Евразийского третичного угленосного пояса выделены две лимнические буроугольные фрормации: трансгрессивная нижнесреднепалеогеновая (палеоцен-среднеэоценовая) УЩ и регрессивная верхнепалеогеннижненеогеновая (олигоцен-миоценовая) дДВ. Отсутствие достоверных данных о положении биостратиграфических границ свит, слагающих палеоцен-среднеэоценовую формацию УЩ, затрудняет проведение региональной и межрегиональной корреляций углевмещающих осадочных и вулканогенно-осадочных отложений.

Несмотря на сложные взаимоотношения осадочных и осадочно-вулканогенных пород и их парагенетических ассоциаций по латерали и вертикали, а также своеобразие кайнозойского торфообразования в различных мегаструктурах древней платформы (малая мощность, невыдержанность по простиранию, частое расщепление и выклинивание, наличие многочисленных следов размыва и переотложения), необходимо продолжить работы по сбору новых данных о вещественном составе и строении пород осадочного покрова с последующим обновлением существующих схем-моделей физико-географических 
и тектонических обстановок фрормирования кайнозойских угленосных и вмещающих их осадочных комплексов пород.

1. Ажгиревич Л.Ф. Буроугольная формация кайнозоя Белоруссии. / Л.Ф.Ажгиревич - Минск: Наука и техника, 1981. - $206 \mathrm{c}$.

2. Александрова А.В. Закономерности кайнозойского углеобразования в пределах Украинского щита и Днепровско-Донецкой впадины. / А.В.Александрова // Тектоника и стратиграфия. - Вып. 37. - С. 38-45.

3. Геологія вуглегазових басейнів (провінцій) України / А.Я. Радзівілл, А.В. Іванова, Л.Б. Зайцева. - Київ: Логос, 2007. -179 c.

4. Геология и нефтегазоносность Днепровско-Донецкой впадины. Стратиграфия / Айзенверг Д.Е., Барченко О.И., Бражникова Н.Е. [и др.]. - Киев: Наук. думка, 1988. -148 с.

5. Днепровский буроугольный бассейн / Радзивилл А.Я., Гуридов С.А., Самарин М.А. [и др.]- Киев: Наук. думка, 1987. -328 c.

6. Дидковский В.Я.,. Стратиграфические подразделения пограничных эоцен-олигоценовых отложений Северной Украины // Докл. АН УССР. Сер. Б. - 1984. - № 8. - С. 9-12. / В.Я. Дидковский, В.А. Зелинская, В.Ю. Зосимович [ и др.]

7. Зосимович В.Ю. Олигоценовые отложения Днепровско-Донецкой впадины. / В.Ю. Зосимович - Киев: Наук. думка, 1981. - 167 с.

8. Зинова Р.А. Олигоценовые отложения Белоруссии и их аналоги на Украине, в Казахстане и Сибири / Р.А. Зинова // Литология, геохимия и стратиграфия континентальных кайнозойских отложений Белоруссии. Минск: Наука и техника, 1988. - С. 111-120.

9. Зосимович В.Ю., Александрова А.В. Событийно-палеогеографические аспекты формирования угленосных отложений Субпаратетиса / В.Ю. Зосимович, А.В. Александрова // Біостратиграфрічні та палєоекологічні аспекти подійної стратиграфії - Київ: ІГН НАН України, 2000. - С. 55-56.

10. Иванов Г.А. Угленосные формации. / Г.А. Иванов - Л.: Наука, 1967. - 407с.

11. Игнатченко Н.А. Угли палеоген-неогена Днепровско-Донецкой угленосной площади. / Н.А. Игратченко, Л.Б. Зайцева.- Киев, 1980. - 56 с. - (Препр. / АН УССР. Ин-т геол. наук; № 80-3).

12. Кирюков В.В. Особенности угленакопления и типы месторождений Днепровско-Донецкого басейна. / В.В. Кирюков // Зап. Ленингр. горн. ин-та. - 1973. Т. 65, - № 2. - С. 125-131.

13. Кирюков В.В. Особенности платформенного палеоген-неогенового угленакопления и некоторые вопросы его оценки: - автореф. дис. ... д-ра геол-минерал. наук. /В.В. Кирюков. - Л.: 1973. - 45 с.

14. Клюшников М.Н. Нижнетретичные отложения платформенной части Украинской ССР. / М.Н. Клюшников. Киев: Изд-во АН УССР, 1953. - 430 с.

15. Крашенинников Г.Ф. Условия накопления угленосных фрормаций СССР. / Г.Ф.Крашенинников. - М.: Изд-во Моск. ун-та. -294 с.

16. Марченко П.Ф. Закономерности размещения бурого угля в олигоценовых отложениях северо-западной части Днепровско-Донецкой впадины. / П.Ф. Марченко // Перспективы поисков полезных ископаемых в Днепровско-Донецкой впадине. - Киев: Наук. думка, 1974. - С. 103-107.

17. Михелис А.А. Вещественный состав и строение буроугольных пластов Донбасса и Днепровско-Донецкой впадины. / А.А. Михелис. // Геология угольных месторождений . - М.: Наука, 1971. - Ч. 2. - С. 201-209.

18. Стратиграфическая схема палеогеновых отложений Украины (унифицированная) / Макаренко Д.Е., Зернецкий Б.Ф., Зелинская В.А. [и др.]. - Киев: Наук. думка, 1987. - 116 с.

19. Уәленосные формации и вещественный состав углей Днепровско-Донецкой впадины / Радзивилл А.Я., Майданович И.А., Иванова А.В. [и др.]. - Киев: Наук. думка, 1990. - 220 с.

\section{А.В. Александрова}

\section{ПРИНЦИПИ ВИДІЛЕННЯ І ПРОСТОРОВО-ЧАСОВІ МЕЖІ КАЙНОЗОЙСЬКИХ БУРОВУГІЛЬНИХ ФОРМАЦІЙ В МЕЖАХ ПІВДЕННО-ЗАХІДНОЇ ЧАСТИНИ СХІДНОЄВРОПЕЙСЬКОЇ ПЛАТФОРМИ}


Враховуючи численні геологічні матеріали вивчення кайнозойських промислових вугленосних відкладів у межах покрівних мегаструктур південно-західної частини Східноєвропейської платформи, виділені палеоген-неогенові буровугільні формації з обгрунтуванням особливостей їх речовинного складу, будови, розповсюдження, розвитку, а також взаємовідношень з оточуючими невугленосними формаційними утвореннями.

Ключові слова: буре вугілля, Український щит, осадові товщі, формаційний аналіз, палеотектоніка

\section{A. Aleksandrova \\ PRINCIPLES OF ALLOCATION AND SPACE-TIME LIMITS OF CENOZOIC BROWN COAL FORMATIONS IN SOUTH-WESTERN PART OF EAST EUROPEAN PLATFORM}

The Paleogene-Neogene lignite formations were allocated substantiating the characteristics of their composition, structure, distribution, development, and relationships with adjacent no-coals formations Given the significant geological study materials Cenozoic industrial coal-bearing deposits within the coating megastructures southwestern part of the East-European platform.

Key words: brown coal, Ukrainian shield, sedimentary sequences, formation analysis, paleotectonics.

Інститут геологічних наук НАН України, м. Київ

Александрова Анжела Володимирівна

Статья поступила: 10.06.2013 